\title{
Speech Therapy Media Modeling Through Contextual Approach for Indonesian Language and Literature Department Students in Surakarta, Central Java
}

\author{
T. Wahyuni ${ }^{1}$, S. Wahono ${ }^{2}$, S. Muryati ${ }^{3}$, N. K. Sari ${ }^{4}$ \\ ${ }^{1-3}$ Indonesian Language and Literature Department, University of Veteran Bangun Nusantara, \\ Sukoharjo, Indonesia \\ ${ }^{4}$ Primary Teacher Education Department, University of Veteran Bangun Nusantara, \\ Sukoharjo, Indonesia \\ tutik21161@gmail.com
}

\begin{abstract}
The article investigated the modeling elements within the learning process by utilizing visual aids to help the students in comprehending the Indonesian Phonology. It aimed to: (1) describe the current physical instruments of Indonesian Phonology used by Indonesian Language and Literature Department students (2) explain the Indonesian Phonology subject by utilizing the modeling elements of Contextual Learning Approach based on the lecturers and students' need analysis (3) explain the speech therapy media development in Phonology through a Contextual Learning model for Indonesian Language and Literature Department students in Surakarta universities. It targeted to provide a modeling element for Indonesian Phonology in the Contextual Learning scope as the implication of the study. A Research and Development (R\&D) Method was carried out to examine the product effectiveness through four procedures, which include: (1) exploration; (2) design; (3) limited experiment; and (4) dissemination.
\end{abstract}

Keyword: Modeling Element; Contextual Approach; Speech Therapy Media.

\section{INTRODUCTION}

The modeling elements in a Contextual Teaching and Learning (CTL) model links the subject focus with the reality in an attempt to enable the students in constructing their knowledge and applying its values for life. As [1] stated that the coverage of Indonesian Phonology as a social dialect describes phonological variations based on phoneme positions in a word (at the beginning, middle, or end) that influences pronunciation [2]. 
A number of studies about contextual approach for Syntax teaching and learning development were previously proposed by [3]-[5]in Scopus-indexed journals. Through the approach, the students are capable in exploring their experiences in an attempt to improve their potential by searching, saving, and applying the concept that they learn. The strategy will train them to comprehend the concept holistically, authentically, and actively.

The current Phonology subject puts less attention to the contextual issues in the social life, in addition to the teachers' tendency to the cognitive area. The conditions only share a limited access for the material development based on the real phenomenon (an interview with the students). The problem arises due to insufficient material resources that rely on the contextual approach for Phonology lecture. The lecturers generally find a difficulty in reconstructing the context of real situation into the learning environment. The condition will eventually discourage a number of meaningful aspects, including discoveries, collaborative team-work, problemsolving capability, variation in teaching, field practice, observation, gradual evaluation, and peer-to-peer learning. Furthermore, the students will be incapable in conveying their experiences due to the lack of motivation in holding inquiry, argumentation, and reflection.

A Contextual Approach helps the lecturers in connecting the subject focus with the real situation of daily life, as [1] explained that the approach could provide real-like circumstances for class learning and encourage the students to apply their knowledge for their daily life. Instead of theoretical transfer from lecturers to students, it offers a natural process of knowledge construction that emphasizes on the process more than the outcome.

As the comparison in defining the research objectives, a number of relevant studies are highlighted. The students required a concept mastery for Phonology, of which a mind map could offer an effective mapping. A Contextual Approach within a learning development would potentially improve their understanding to the Linguistics conception [6]. The Acquisition of Communicative Competence from the Journal of Language Teaching and Research found out that communicative competence covered Linguistics interaction within a spontaneous conversation involving some people through the target language [7]

\section{METHOD}

The methodology explains the research design and procedure in detail, which comprises of four stages, including: (1) exploration; (2) design; (3) limited experiment; and (4) dissemination. It aims to develop a specific product [10] in the form of Indonesian Phonology textbook that adopts a Contextual Approach for Indonesian Language and Literature students in Surakarta universities. Research and Development (R\&D) Method basically focuses on the model development, targeting to design a new product and procedure through a standard technical test, evaluation, and improvement based on a number of criteria, which include effectiveness, quality, and characteristics.

The procedure ranged from the comprehension of theoretical reviews to analyzing the existing programs in an attempt to develope a new product based on the limited experiment. It aimed to generate a number of research aspects in regards to the model development, including research design, procedure, expert involvement, setting, subjects, researcher's role, data collecting technique, data validity test, and data analysis. The method comprised of four stages, including: (1) exploration; (2) design; (3) limited experiment; and (4) dissemination. Meanwhile, the procedure consisted of three stages, including: (1) exploration of the previous textbook through content analysis and need analysis; (2) Indonesian Phonology textbook 
development using Contextual Approach; and (3) experiment which consists of seven phases, including: (a.) concept mapping relating to its composition, systematics, and references; (b.) prototype arrangement; (c.) initial testing for the stakeholders through workshops involving Indonesian Language and Literature lecturers in Surakarta universities; (d.) assessment by Phonology and textbook experts; (e.) limited experiment; and (f.) wider-range experiment in different institutions in an attempt to compare the effectiveness of contextual and conventional textbook through a before-after experimental design for the control and experimental group.

The research produced benefits from each stage of development. The exploration stage produced four benefits, which comprised of: (1) information of previous textbooks' features; (2) information of previous textbook types deployed in Surakarta universities; (3) information of textbooks' contents, including theoretical reviews, concepts, and practical guidelines; and (4) information of need analysis relating to the textbook development using a Contextual Approach. Meanwhile the development stage produced the prototype of Indonesian Phonology textbook using a Contextual Approach for the lecturers and students, the experimental stage produced the evidence of the textbook effectiveness. The discovery implied that the Indonesian Phonology textbook developed through a Contextual Approach had contributed a more stunning learning outcome compared to the conventional one.

\section{RESULT AND DISCUSSION}

The phonological analysis revealed that a CTL modeling comprised of abridgment such as construction and acronym, in addition to modification. The technique covered a number of phenomena, including the affixation by using the suffix -in, the dominant use of /e/ and /o/ vowels in teenage lingua franca, the play of intonation, vowel combination, and curt conversation among teenagers [8].

Indonesian Phonology differs from other languages, especially those that depend on the regional dialects, such as Madura Language which is generally spoken as Madura people's lingua franca. In the discussion of Linguistics coverage, Madura Language contains four main dialects, which include (1) Sumenep dialect (2) Pamekasan dialect (3) Bangkalan dialect, and (4) Kangean dialect, and sometimes is added by (1) Pinggirpapas dialect, and (2) Bawean dialect. Madura and Indonesian Language belong to the Austronesian language family, as both of the languages show significant similarities in terms of phonology and phonemic correspondence [9].

In regards to the discussion, what are the Madura Language's phonemes (including vowels, consonants, and diphthongs)? Does it show uniqueness in its phonemic distribution? How is its phonemic uniqueness if compared to Indonesian language's?

The concrete action for the selection consists of: (1) prototype testing using a Contextual Approach; (2) prototype development in terms of content, material presentation, and acceptance for the lecturers and students; (3) identification of the prototype shortages; (4) improvement based on need analysis; (5) study of the prototype expedience based on the relevant theories and field observation; (6) Focus Group Discussion (FGD) that involves a number of experts in Indonesian Phonology and textbook and Indonesian Phonology lecturers; and (7) gradual development cycle in an attempt to reach the standard expected by the stakeholders relating to the textbook development. 
Table 1. Experimental Phase for Indonesian Phonology Textbook Development

\begin{tabular}{llll}
\hline Syllable & Word & Phrase & Sentence \\
\hline Tra & Set & Buku tulis & Adik menangis. \\
\hline Tri & Saat & Bola bundar & Budi belajar Bahasa Indonesia. \\
\hline Tru & Suap & Meja tamu & \\
\hline Tre & Soal & & \\
\hline Tro & Sibuk & & \\
\hline
\end{tabular}

The finding confirms that there is a difference of pre-test and post-test results from the control and experimental group.

Table 2. Independent Sample T-Test

\begin{tabular}{cccc}
\hline Data & $T$ & Sig & Conclusion \\
\hline $\begin{array}{c}\text { Equality Test } \\
\text { (Pre-Test) }\end{array}$ & -0.546 & 0.588 & There is no significant difference \\
\hline T-Test & 2.239 & 0.030 & There is a significant difference \\
$\begin{array}{c}\text { (Difference of } \\
\text { Pre-Test and }\end{array}$ & & \\
Post-Test & & & \\
Scores) & & & \\
\hline
\end{tabular}

The Independent Sample T-Test confirms that there is a significant difference in the pretest and post-test scores between the control and experimental group. Meanwhile the control group secured 75.64 for their mean of post-test scores, the experimental group afforded 81.05. The finding implies a higher result of the experimental group that deployed the contextual textbook compared to the control group that deployed the conventional one (see the comparison diagram of pre-test and post-test scores between the control and experimental group).

\section{CONCLUSION}

The current study relating to the speech therapy revealed that the Contextual Approach had proved a more effective result than the Conventional Approach. It could offer a significant improvement for the students' independence in learning activities and interaction, in addition to the reduction of their spoon-feeding habit.

Indonesian Phonology is simpler than other languages such as Madura that contains six vowels, 31 consonants, three diphthongs, and eight clusters. Meanwhile Indonesian Language has six vowels, which include $/ a /, / i /, / u /$, /e/, and /o/; Madura Language has three diphthongs, which include /ay/, /oy/, and /uy/.

In regards to the lecturers and students' need analysis, the study implied that the modeling of speech therapy media could help the therapists in improving the patients' speech healing process through repetitive gradual exercises, which include pronouncing syllables, words, phrases, and sentences. Other activities such as a tongue-twister exercise could also help in flexing the tongue muscles. 


\section{ACKNOWLEDGMENTS}

The researchers express their thanks, appreciation and achievement to Universitas Veteran Bangun Nusantara Sukoharjo and Universitas Muhammadiyah Malang of ICASE 2018 conference so this research can be published.

\section{REFERENCES}

[1] Nurhadi and A. G. Senduk, Pembelajaran Kontekstual dan Penerapannya dalam KBK. Jakarta: Depdiknas, 2004.

[2] M. Taembo, "Social Dialect Study of Indonesian Phonology," Kandai, vol. 12, no. 1, p. $1-16 ., 2016$.

[3] Wahyuni, Tutik, S. S, S. . Slamet, and E. All, "The Content of Indonesian Language Syntactic Learning Instrument Base don The Need Analysis Directed to The Indonesian Language And Literatur Education Departement Students Among The Universities in Surakarta Indonesia,” Anatol. J. Educ., vol. 1, no. 3, pp. 1-10, 2015.

[4] T. Wahyuni, "Contextual Approach to the Development of an Indonesian Syntax Textbook," High. Educ. Indones., vol. 11, no. 2, pp. 211-226, 2018.

[5] Wahyuni, Tutik, S. S, S. . Slamet, and E. All, "Development of Teaching Materials Syntax: Indonesian Sentence Contextual Approach to Education for Indonesian Language and Literature Students in Surakarta Indonesia," in Proccedings Cambodia, 2017, p. 1052.

[6] Sudaryanto, "Peningkatan Penguasaan Konsep Sintaksis Bahasa Indonesia melalui Penerapan Media Peta Konsep pada Jurusan Pendidikan Bahasa dan Sastra Indonesia," J. Litera, vol. 6, no. 1, 2007.

[7] C. Zhan, "Acquisition of Communicative Competence," J. Lang. Teach. Res., vol. 1, no. 1, 2010.

[8] Sartini and N. Wayan, "Bahasa Pergaulan Remaja: Analisis Fonologi Generatif," Mozaik J. Ilmu Hum., vol. 12, no. 2, pp. 92-209, 2012.

[9] Sofyan and Akhmad, "Fonologi Bahasa Madura," J. Hum., vol. 22, no. 1, pp. 207-218, 2010. 